\title{
Strategies for hepatitis B virus screening of Polish blood donors (2005-2020)
}

\author{
Aneta Kopacz $\odot$, Piotr Grabarczyk $\odot$ \\ Department of Virology, Institute of Hematology and Transfusion Medicine, Warsaw
}

\begin{abstract}
Summary
The risk of hepatitis $B$ virus (HBV) transmission through blood and blood components is markedly reduced through serologic testing of each donation for the presence of $H B V$ infection markers. Testing for hepatitis B virus surface antigen (HBsAg) is obligatory almost everywhere in the world. Several countries have also implemented testing for antibodies to hepatitis $B$ core antigen (anti-HBc) and some perform HBV DNA tests, either in single donations or minipools of up to 96 donations. In countries with obligatory hepatitis $B$ vaccination, the incidence of $H B s A g$-positive infections has been on the decline. Questions are therefore raised regarding the choice of optimal strategies for blood donor screening.

In Poland, screening for hepatitis B virus surface antigen (HBsAg) to identify HBV infected donors was initiated in 1971. Pursuant to the guidelines of the Council of Europe, the analytical sensitivity of $0.13 \mathrm{IU} / \mathrm{ml}$ is required for a HBsAg screening test to detect a HBsAg-positive infection. In 2005, HBV-DNA testing was added to the panel of screening tests for further reduction of $H B V$ transmission risk through blood and blood components.

The study presents the analysis of the HBsAg and HBV-DNA screening tests used in Poland so far. The analysis is based on the author's doctoral dissertation and the outcome may largely contribute to the process of determining the effectiveness of the methods used up to date and to development of an optimal panel of HBV screening tests for Polish blood donors.
\end{abstract}

\section{Key words: hepatitis B virus (HBV), HBV screening tests, HBV-DNA, HBsAg}

J. Transf. Med. 2021; 14: 73-86

\section{Introduction}

Hepatitis B virus (HBV), responsible for a wide spectrum of liver diseases ranging from acute to chronic, is one of the most significant clinical and epidemiological challenges worldwide [1]. HBV is transmitted through blood, semen and other body fluids of infected persons. Due to the high infectivity of HBV transmitted through blood, blood transfusion services worldwide are actively involved in controlling the risk of transfusion transmitted HBV (TT-HBV). Blood from phases with detectable antigen HBs (HBsAg) and the highest viral load characteristic of symptomatic hepatitis $\mathrm{B}$ has been found the most infectious. However, TT-HBV may also occur through blood from phases with no detectable HBsAg - usually with lower viral load and asymptomatic course [2]. The first method of reducing the risk of TT-HBV is the qualification of the blood donor (based on medical

Correspondence address: PhD of medical science Aneta Kopacz, Department of Virology, Institute of Hematology and Transfusion Medicine in Warsaw, Chocimska Street 5, 00-957 Warszawa, e-mail: akopacz@IHTM.waw.pl

Translation: mgr Krystyna Dudziak

This article is available in open access under Creative Common Attribution-Non-Commercial-No Derivatives 4.0 International (CC BY-NC-ND 4.0) license, allowing to download articles and share them with others as long as they credit the authors and the publisher, but without permission to change them in any way or use them commercially. 
history and physical examination). As many as $2 / 3$ of infected people are asymptomatic or present non-specific symptoms, so despite donor qualification procedures, HBV is still a serious risk factor for transfusion-related adverse reactions. In the recent years, development of pathogen inactivation methods has become increasingly significant. Unfortunately they are not fully effective and the accessibility is limited [3, 4].

To minimize the transfusion-related risk of HBV transmission various HBsAg, HBV DNA and anti-HBc screening tests are in use worldwide. HBsAg screening tests are capable of detecting acute and chronic infections though not in all phases and forms due to insufficient test sensitivity [5]. The obligation to test individual donations for HBsAg is imposed by Directive 2002/98/EC defining the quality and safety standards for the collection, testing, preparation, storage and issue of human blood and blood components. The test is also recommended by the Council of Europe [6, 7]. On the other hand, HBV DNA screening tests implemented in 2002 identify not only HBsAg-positive phases (with detectable $\mathrm{HBsAg}$ ) but also HBsAg-negative phases (with undetectable HB$\mathrm{sAg}$ ). Nucleid Acid Testing (NAT) for HBV is used by 40 countries worldwide and various strategies are employed ranging from single donation testing (IDT) to mini-pool tests of 96 donations (MP96) [8]. In several European countries as well as in the USA and Japan, each donation is also screened for anti-HBc - a marker of ongoing and past infection.

Better quality and availability of tests as well as possibility of identifying various infection stages triggered discussions on the optimal choice of screening tests (markers and algorithms) for detection of the largest possible number of infected donors $[9,10]$ while availability of blood for transfusion is ensured i.e. by not deferring people whose blood does not transmit the virus.

Before joining the discussion, we decided to first summarize and present the algorithms used so far for HBV-DNA testing in Polish Blood Transfusion Centers (BTC).

\section{HBV infection markers - course of infection}

HBV infection is a dynamic process. The course of HBV infection and its markers depend on viral load and immune response (Fig. 1) [11]. In a couple of weeks following the eclipse phase the HBV markers appear in blood in the same sequence regardless of the course of infection (asymptomatic, acute or chronic) [12]. During the first weeks after exposure the virus replicates and intensive protein expression occurs (increment of hepatitis viral load in liver) as demonstrated by higher HBV-DNA and HBsAg levels in blood. The period of time between infection and reliable test detection is called the I window period (WP 1) $[13,14]$. From the 6 th week onwards, anti-HBc antibodies are detected: first IgM, then IgG. High $\mathrm{IgM}$ anti-HBc antibody concentration persists for 2-6 months and is characteristic of acute infection [15]. Acute viral hepatitis may present with elevated level of aminotransferase (ALT), jaundice and flu-like symptoms [16].

If the acute-phase infection is self-limiting, $\mathrm{HBsAg}$ is no longer detectable in blood within 6 months and clinical symptoms (including hepatitis), if previously observable, now disappear while laboratory parameters (such as elevated ALT level) become normal. One of the last periods of self- limiting infection is the II Window Period (II WP) when HBsAg concentration decreases to undetectable values in the presence of anti-HBc IgM antibodies and low levels of HBV DNA. HBV DNA and HBeAg in blood are usually absent as well. Detectable are antibodies to virus antigens: anti-HBc with or without anti-HBe and anti-HBs [14]. Persistence of HBsAg with no HBV DNA may indicate self- limiting infection which was accompanied by integration of hepatitis virus $\mathrm{S}$ gene the pre-S/S fragment into the host genome [17, 18]. On the other hand, the prolonged presence of HBV DNA, at a level below $200 \mathrm{IU} / \mathrm{ml}$, with undetectable HBsAg with or without anti-HBc and/or anti-HBs in blood is suggestive of incomplete control of the immune system over virus replication i.e. transition to Occult Hepatitis B Infection (OBI) $[17,19]$.

In case of non self-limiting infection, $\mathrm{HBsAg}$ and usually HBV DNA are detectable in blood for $>6$ months and the infection is chronic. HBsAg and anti-HBc are detected for months/years while HBV DNA and HBeAg are present depending on the infection phase. Anti-HBe and anti-HBs antibodies are undetectable and the infection is periodically asymptomatic. Chronic as well as acute phase infection may pass into inactive $\mathrm{HBsAg}$ carrier state with undetectable HBV DNA or occult HBV infection [19, 20].

\section{Blood donor screening for HBV infection markers}

\section{HBsAg testing}

The HBs antigen (HBsAg) is the first serological marker of HBV infection which is detectable with immunological methods. With routine tests 


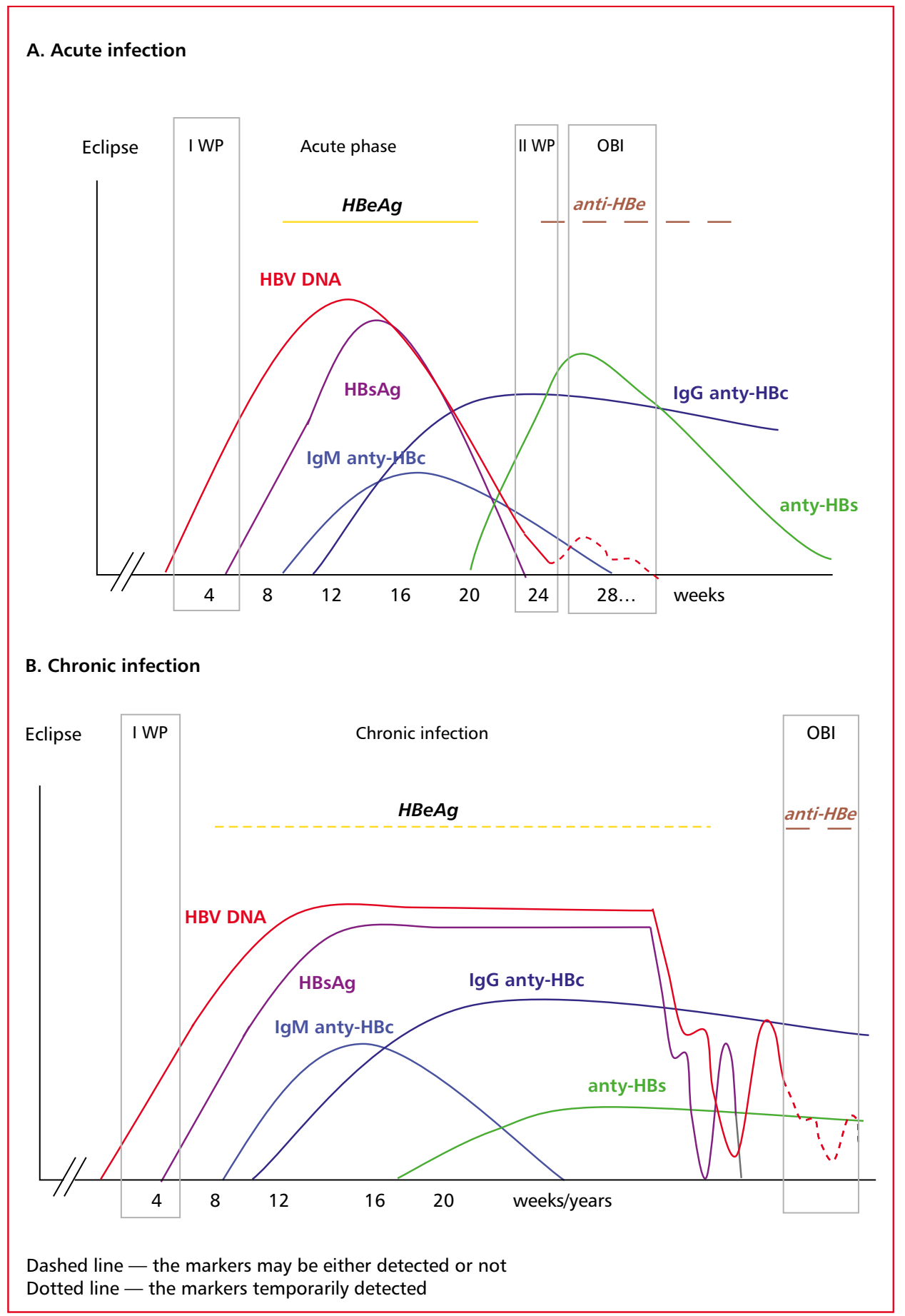

Figure 1. Course of HBV infection - I WP, II WP and Occult HBV Infection (OBI) [14, 21])

(0.05-0.5 IU/ml sensitivity) HBsAg can be detected in blood as of $4^{\text {th }}$ week of infection (2-10 weeks) [15]. According to Korelitz, in acute self-limiting infection HBsAg is detected for an average of 63 days. Decline of HBsAg concentration occurs, among others, as a result of the neutralizing effect of anti-HBs antibodies [14, 22]. The presence of HBs antigen in the acute and chronic infection phase positions it as the most important serological marker both diagnostically and clinically. Following the Council of Europe recommendations, screening tests should detect at least $0.13 \mathrm{IU}$ of $\mathrm{HBsAg} / \mathrm{ml}$ in blood [7]. The analytical sensitivity of the HBsAg test is verified on the basis of the test of international panels (International Standard, IS; Paul Ehlrich-Institut, PEI). Scheiblauer's analysis of $70 \mathrm{HBsAg}$ tests showed that only 23/51 EIA tests and $0 / 17$ rapid tests had the sensitivity of 
$\leq 0.13 \mathrm{IU} / \mathrm{mL}$ in the PEI HBsAg Standard subtype ad trial. Moreover, the examination of a panel of the most common $\mathrm{HBV}$ genotypes $(\mathrm{A}-\mathrm{F})$ revealed different sensitivity of the tests for each genotype. As many as 6/23 tests detecting $0.13 \mathrm{IU} \mathrm{HBsAg}$ $\mathrm{PEI} / \mathrm{ml}$ had lower sensitivity in relation to 2 or more tested genotypes. Scheiblauer also showed that the sensitivity of HBsAg tests may be different as regards HBV mutants. There are a number of recognized $\mathrm{HBV}$ genome mutations that induce amino acid changes, e.g. M133L, P105R, T131L, Q101H, S143L. These render HBsAg undetectable by tests of sensitivity $\leq 0.13 \mathrm{IU} / \mathrm{ml}$ or reduce the likelihood of detection as compared to standard phenotype [23]. In order to detect the highest possible number of HBV polymorphs, the selection of the screening test should therefore be preceded by an analysis of the test sensitivity against as many HBV polymorphs as possible. In 2017 and 2018, new enzyme immunoassay methods were described with sensitivity of $0.0005-0.005 \mathrm{IU} \mathrm{HBsAg} / \mathrm{ml}$. The studies of Shinkai N. et al. and Deguchi M. et al. demonstrate the most recent HBsAg tests to be almost as effective for viremia detection as NAT tests. Their effectiveness in blood transfusion has not however been evaluated $[24,25]$.

\section{anti-HBc}

Antibodies to HBV core antigen (anti-HBc) are important diagnostic markers of $\mathrm{HBV}$ infection. During acute infection phase anti-HBc IgM and IgG of the same specificity appear 1-2 weeks after the presence of HBsAg. IgG antibodies which follow $\mathrm{IgM}$ are considered persistent infection markers. In the acute infection phase anti-HBc IgM persist for 2-6 months- most of the time at high concentration and then wear off [4]. Anti-HBc IgM may also appear in exacerbation stages of chronic infection but at concentrations lower than in in the acute infection phase $[4,15]$. In fulminant hepatitis $B$ cases with enhanced immune response that eliminates hepatocytes with multiplied HBV, anti-HBc IgM may be the only detectable serological marker of infection. There are also reports of infections in which anti-HBc is not detected $[26,27]$.

In some countries, mostly with low endemicity of HBV, blood donors are screened for anti-HBc. The test is not common mostly due to low specificity (estimated at 16-75\%), as well as difficulties with interpretation of results for lack of confirmation test. Failure to rule out false-reactive results obviously must lead to donor loss. The anti-HBc test is not used in countries with high and medium endemicity of $\mathrm{HBV}$ where the number of anti-HBc carriers with no HBsAg exceeds 5\%. Deferral of donors with anti-HBc would lead there to reduction in the supply of blood and blood components [28].

\section{DNA HBV - molecular marker}

HBV DNA is detectable in blood during most stages of infection when the virus replicates in the liver [21, 29, 30]. Due to high sensitivity molecular diagnostic tests (95\% LOD below 200 IU DNA $\mathrm{HBV} / \mathrm{ml}$ of plasma) based either on techniques of Transcription Mediated Amplification (TMA) or polymerase chain reaction (PCR), the HBV infection can be detected not only in HBsAg-positive phases but also in HBsAg-negative phases as WP and OBI when HBsAg is undetectable [31-34]. NAT testing also identifies HBV polymorphic forms undetectable in HBsAg testing due to antigen mutant conformation caused by the so-called escape mutations [35]. Directive 2002/98/EC poses no obligation on EU countries to test HBV DNA in blood donors. However, such tests are recommended by the Council of Europe and implemented both in high- and low-endemic countries as they contribute to minimizing the transfusion-transmitted HBV (TT-HBV) risk by identifying cases of HBsAg-negative infection $[6,7,36]$.

\section{HBV DNA in blood during the early \\ HBsAg-negative stages of infection}

The currently available HBV diagnostic tests based on NAT such as polymerase chain reaction (PCR) and transcription mediated amplification (TMA) enable identification of HBV infection even before HBsAg appears, i.e. in the I serological window [14]. The HBV median doubling time is about 2.6 days (2.2-15.2) and is relatively slow as compared to e.g. HIV or HCV. The slow rate of HBV multiplication implies relatively long time for the viral load to reach levels detectable with diagnostic methods [2]. The probability of HBV DNA detection in the 1st WP depends therefore on the sensitivity of the test [29]. The NAT method (sensitivity of $3.4 \mathrm{IU} / \mathrm{ml}$ ) allows for detection of the genetic material of HBV as early as 3 weeks before HBs antigen, provided the minimum sensitivity HBs antigen test is $0.13 \mathrm{IU} / \mathrm{ml}$ [37]. Detection HBsAg after approximately 4 weeks of viral multiplication, i.e. when HBV DNA concentration exceeds $3 \times 10^{2} \mathrm{IU} / \mathrm{ml}$, marks the end of the serological window phase [38, 39].

In self-limiting acute infections, after about 2 month presence of HBsAg in blood, the DNA concentration is reduced by half every $1.6(0.9-6.3)$ days [13]. Reduction of viremia is associated with 
HBe and HBs seroconversion as well as neutralization of HBsAg particles [15]. Effective limitation of infection involves a 10-day serological window II during which HBs antigen is undetectable at HBV DNA below $10^{3} \mathrm{IU} / \mathrm{ml}$ and the presence of both class anti-HBc antibodies. Using a mathematical model, Vermeulen et al estimated that the genetic material of the virus should be detectable with NAT test (sensitivity of $3.4 \mathrm{IU} / \mathrm{ml}$ (95\% LOD) during 8.7/ /of the 10 days of II WP [14].

\section{HBV DNA in occult HBV infection}

Occult HBV infection (OBI) is a form of infection characterized by HBV DNA replication in the liver with or without HBV DNA detected in peripheral blood of HBsAg-negative men with or without other serologic markers of previous viral exposure [40, 41]. HBV DNA blood levels in OBI fluctuate, resulting in alternating presence or absence of DNA-emia every several weeks/months/ /years [42-44]. In most identified occult infections, DNA-emia in blood did not exceed $200 \mathrm{IU} / \mathrm{ml}$. Analysis of OBI serological markers revealed anti-HBc and/or anti-HBs antibodies in at least $80 \%$ of cases (the so-called seropositive OBI) and in $1-20 \%$ of cases the antibodies were undetectable (the so-called seronegative OBI) [40, 41]. In over $90 \%$ of seropositive OBI cases, anti-HBc antibodies were detected either with or without anti-HBs. In the remaining few percent of seropositive OBI cases, anti-HBs antibodies are detectable with no anti$-\mathrm{HBc}$. These are the so-called cases of "OBI with only anti-HBs present" [34].

\section{The risk of HBV transmission by transfusion and methods of minimizing the risk}

By 1970 approximately $6 \%$ of world population subjected to multiple transfusions of blood components were found infected. The risk of TT-HBV infection was reduced to $0.6-2.22 /$ million donations in low-endemic countries and up to $22.9-45.5 / \mathrm{mil}-$ lion donations in high-endemic countries after implementation of HBsAg screening and deferral for donor candidates and donors who reported hepatitis $\mathrm{B}$ in the pre-donation questionnaire and medical interview or whose behavior suggested higher infection risk [10]. With additional HBV DNA tests, the residual risk of TT-HBV is estimated to be several fold lower, within the range of 0.13-0.6/ /million donations in low-endemic countries and: more than $100 / \mathrm{mln}$ in high-endemic countries. The TT-HBV risk has been found dependent on the epidemiological situation among donors, the sensitivity of screening tests and the mathematical models used for risk estimation [10, 28]. The recent OBI analyzes indicate that TT-HBV in Poland significantly exceeds 0.6 /million donations and is one of the highest worldwide [10].

\section{HBV screening of Polish blood donors; 2005-2020}

In the years 2005-2020, the identification of HBV infections in Polish blood donors was based on HBsAg and HBV DNA screening tests performed in public blood establishments (Blood Transfusion Centers, BTC). The testing procedures followed the IHTM recommendations specified in subsequent versions of the "Medical Standards for Collection, Preparation and Issue/Distribution of blood and blood components in organizational units of the public blood transfusion service" (published since 2006) as well as the Decree of the Minister of Health of June $9^{\text {th }} 2017$ as regards Requirements of good manufacturing practice referring to collection, testing, preparation, storage, issue and transport of blood and blood components for organizational units of the public blood transfusion service, as amended [45-48]. HBsAg was always tested in single donations, while HBV DNA either in single donations or equal volume plasma pools from " $n$ " donor samples $(n=24$ or 8 or 6 or 4$)$.

\section{HBsAg screening tests}

In 2005-2008, HBs antigen screening was performed in single donations with enzyme immunoassays: Hepanostica Uniform II (BioMerioux, Lyon, France) or EIA System 3 (Ortho Clinical Diagnostics, Raritan, NJ, USA). Since 2007, these assays were successively replaced by the chemiluminescent assays (CMIA) Architect HBsAg Qualitative or Quantitative (Abbott Diagnostics, Germany), and since 2010 also Vitros HBsAg ES (Ortho Clinical Diagnostics Inc., NJ, USA). Since 2017, blood transfusion centers (BTC) switched to electrochemiluminescence method "ECLIA" Elecsys (Roche Diagnostics GmbH, Germany) and Monolisa HBsAg Ultra (Bio-Rad, France). Following recommendations, BTC purchased tests in tender procedures and used different tests in different time periods (Fig. 2). The analytical sensitivity of all tests allowed detection of at least 0.13 IU HBsAg IS/ml. Scheiblauer performed studies on clinical sensitivity of HBsAg tests. The studies revealed different sensitivity for the A-F genotypes. All tests however, with the exception of Ortho EIA 


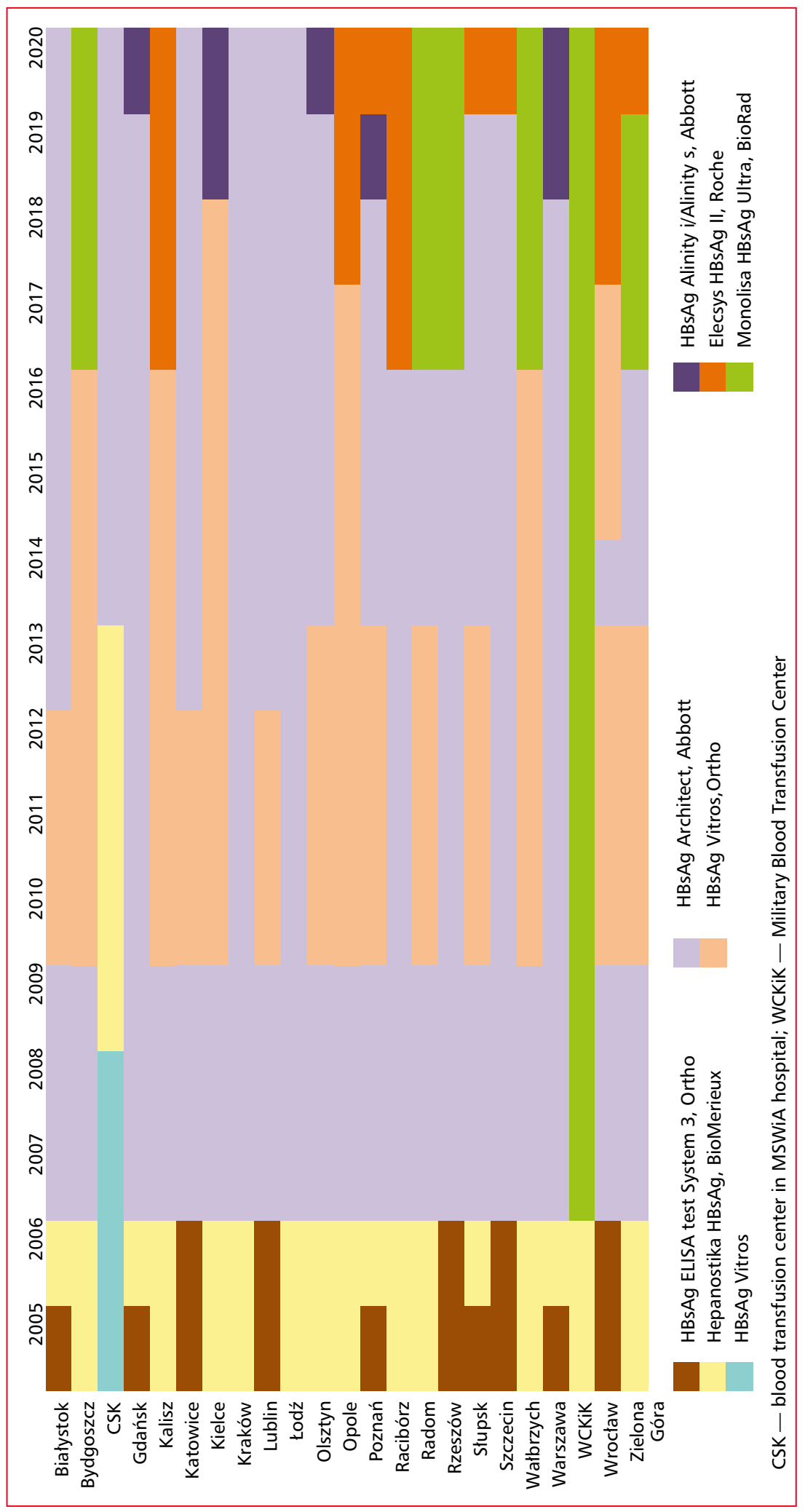

Figure 2. Methods of HBsAg screening used in Polish blood transfusion service (2005-2020) 


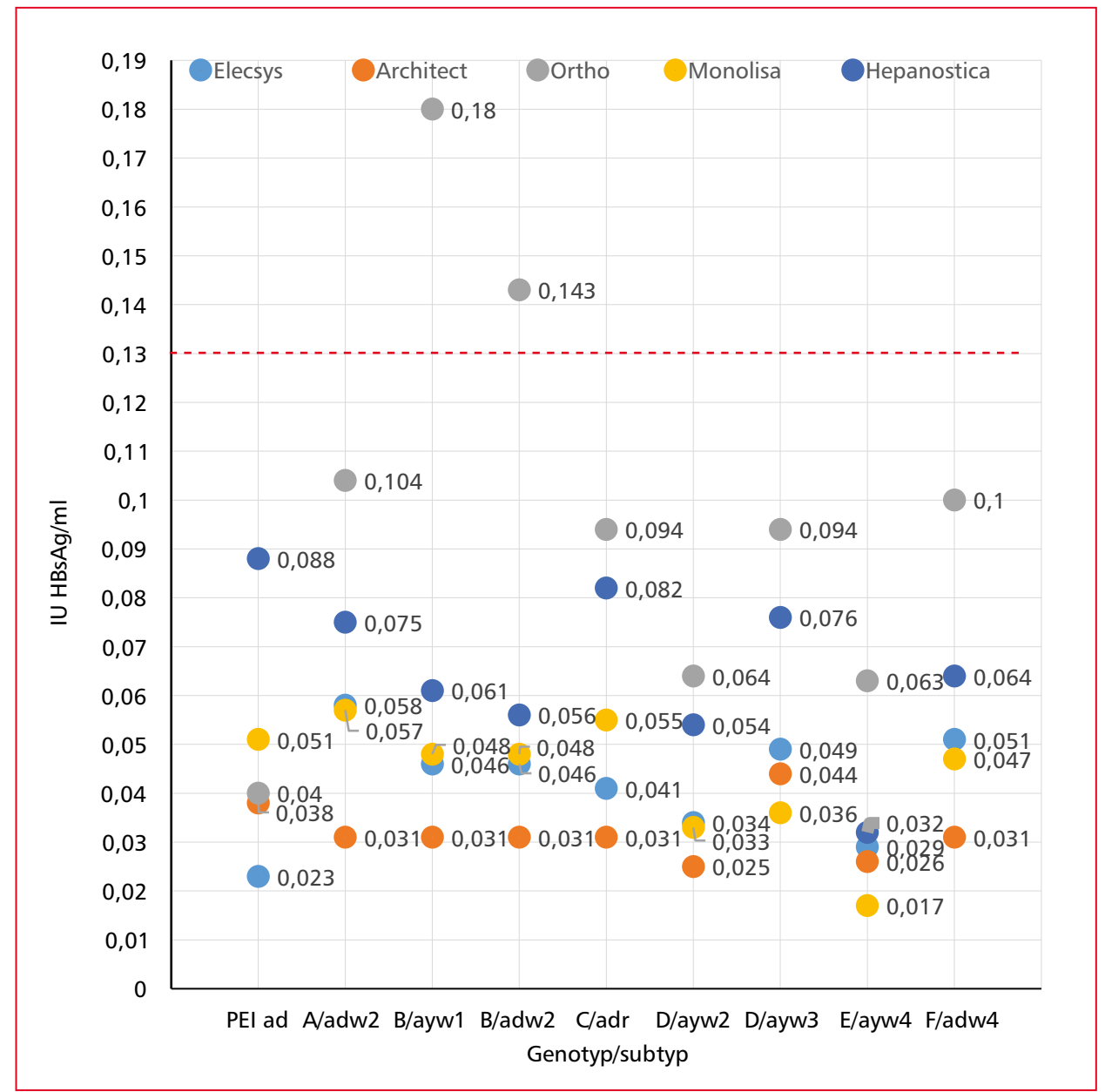

Figure 3. Clinical sensitivity of HBsAg test used in BTC in 2005-2020 [23]

System 3, allowed detection of $0.13 \mathrm{IU} \mathrm{HBsAg} / \mathrm{ml}$ (Fig. 3). The sensitivity of Ortho EIA System 3 test was lower in relation to genotype $B$ of the ayw 1 and adw2 serotypes and did not detect $0.13 \mathrm{IU} \mathrm{HBsAg} / \mathrm{ml}$ of these polymorphic forms. It should be noted however that the Ortho test, like all the other tests used in Poland, detected infection in all 146 positive samples of the genotype panel, including $12 \mathrm{~B} /$ adw2 and $17 \mathrm{~B} /$ ayw1 and polymorphic forms with M133L (0.21 IU/ml), P105R (0.22 IU/ml), T131L (0.36 IU/ml), Q101H (72 IU/ml), S143L (> $8000 \mathrm{IU} / \mathrm{ml})$ mutations [23].

In the same period, obligatory HBV DNA tests were performed in Polish blood transfusion service. Changes in the HBsAg screening methods used in 2005-2020 are presented in Figure 2, and those for HBV DNA are shown in Figure 4. The implemented algorithms for HBV screening and confirmation rely both on serological and molecular methods.

A sample reactive in the screening test was labelled Initial Reactive (IR) and according to the applicable algorithm, the test was repeated twice on the same sample. If both results were negative, the IR donation was considered biological false reactive (BFR) and if no HBV DNA was detected, the donation could be issued for clinical use. A repeat reactive donation ( $\geq 2$ reactive results/ $/ 3$ performed tests) could not be issued for clinical use and the confirmation procedure was launched (neutralization test and/or individual donation test for HBV DNA). A positive result of the confirmation test indicated the presence of HBs antigen in the tested sample.

\section{HBV DNA screening tests}

HBV DNA testing was performed according to two alternative strategies: in individual donations (ID) or in plasma minipools (MP) of 24 (MP24), 8 (MP8), 6 (MP6) or 4 (MP4) donations.

In the article, the sensitivity of NAT tests and the test formats (IDT/pool) used for HBV detection in donor plasma was represented as $95 \%$ limit of detection (95\% LoD) taking into account the dilution with pooled donations. 


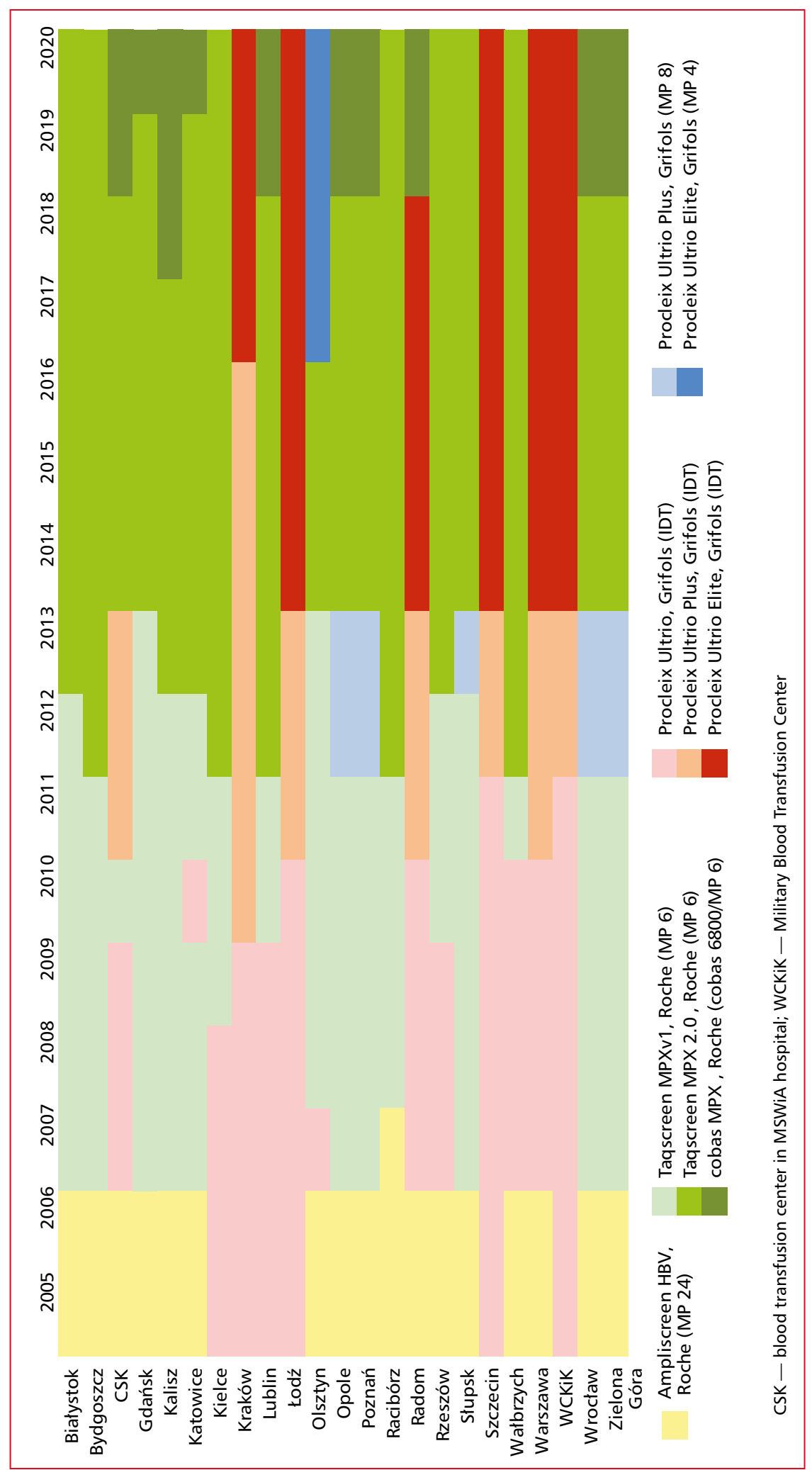

Figure 4. Methods of HBV DNA screening in Polish blood transfusion service (2005-2020) 
Single donation screening was performed with TMA tests while PCR and TMA tests were used for pool testing (Fig. 4). 24-donation MPs were tested with Ampliscreen HBV test, which detected only HBV DNA. The remaining tests were multiplex, i.e. they allowed simultaneous detection of 3 viruses (HBV, HCV and HIV). Recognition of the detected virus required additional discriminatory testing (Table 1 ). Only $2 / 7$ multiplex test (Taqscreen MPX2 and cobas MPX) were capable of identifying the detected virus.

Tests and systems of testing were selected by BTC according to current tender procedures and following 2011 guidelines for detection of $24 \mathrm{IU}$ HBV DNA/ml in donation [47-48].

In 2005-2020, the sensitivity of PCR-based tests increased from 4.4 to $1.4 \mathrm{IU} / \mathrm{ml}$ and sensitivity for donation tested in pools from 105,6-8,4 IU/ml. In 2007 the increase in the sensitivity of PCR based test was brought about by the shift from Ampliscreen HBV (95\% LOD $4.4 \mathrm{IU} / \mathrm{ml}$ ) to Taqscreen MPXv1 (3.8 IU/ml) as well as reduction of plasma pool from 24 to 6 donations. In the years that followed, sensitivity of PCR-based tests performed in the MP6 was brought about by higher sensitivity of the subsequent versions of the MPX test. The sensitivity of the TMA-based tests varied from 2.1 to $10.4 \mathrm{IU} / \mathrm{ml}$ and sensitivity for donation tested in pools from $16,8-17,2 \mathrm{IU} / \mathrm{m}$ ). The sensitivity for donation screened by TMA based tests was subject to smaller changes than the PCR based tests, because until 2011 the former were performed only in single donations. Since 2011, the recommended test format (according to guidelines) had to detect $24 \mathrm{IU}$ of HBV DNA in $1 \mathrm{ml}$ of donation.

In the period 2005-2020, some BTC (Fig. 4) used tests produced by Gen-Probe Incorporated (San Diego, USA), based on TMA method (initially PROCLEIX ULTRIO Assay, and the subsequent versions: PROCLEIX ULTRIO PLUS Assay, PROCLEIX ULTRIO ELITE Assay). Others used only PCR based tests (Ampliscreen HBV) and real-time PCR (Taqscreen MPX v.1, Taqscreen MPX v.2, cobas MPX) by Roche Molecular Systems (South Branchburg, USA). Some BTC worked interchangeably with TMA and PCR based method.

In 2005-2006, HBV DNA donor screening was performed in single donations or 24 donation plasma pools. Since 2007, MP24 screening were successively replaced with single donation tests (sensitivity of $10.4 \mathrm{IU} / \mathrm{ml}$ - Ultrio test) or with 6 donation plasma pools. The change of test (from Ampliscreen to Taqscreen MPXv1) and pool size (from MP24 to MP6) induced change in screening

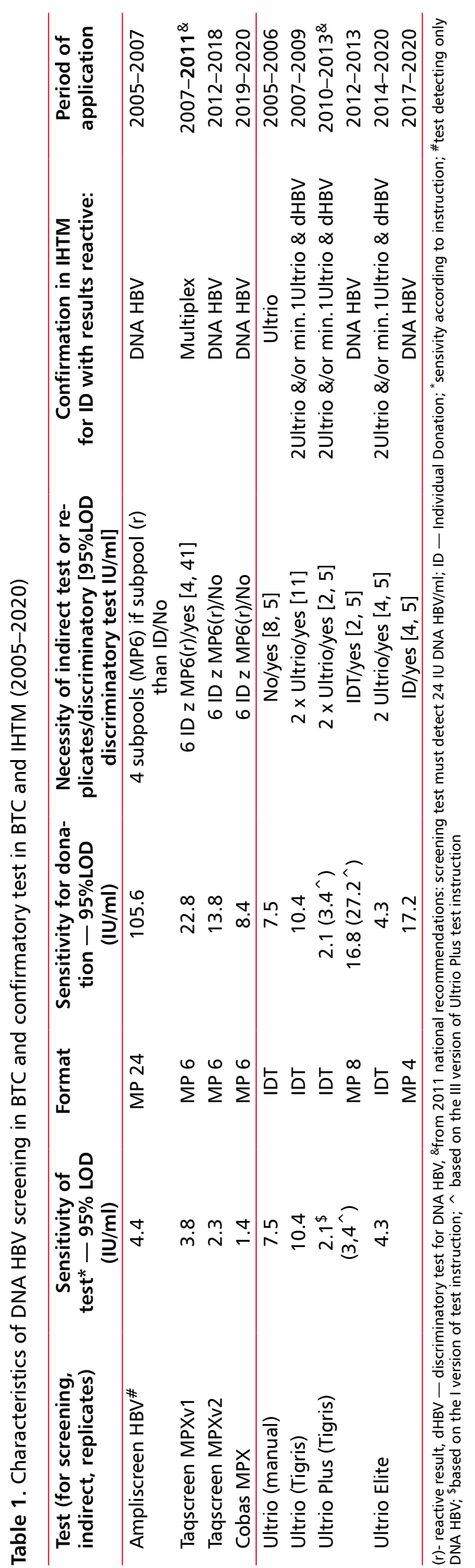


sensitivity from $105.6 \mathrm{IU} / \mathrm{ml}$ to $22.8 \mathrm{IU} / \mathrm{ml}$. Since 2011, the Ultrio test has been gradually replaced with higher sensitivity $(95 \% \mathrm{LOD}=2.1 \mathrm{IU} / \mathrm{ml})$ Ultrio Plus. In the 2012-2014 period, donor samples from 4 BTC were tested in 8 donation pools using the Ultrio Plus test (sensitivity for donation $16.8 \mathrm{IU} / \mathrm{ml}$ ). Since 2014, the Ultrio Plus test manufacturer reported slightly lower sensitivity as compared to previous values (3.4 vs. $2.1 \mathrm{IU} / \mathrm{ml}$ ). Since 2012, the Taqscreen MPXv1 test was replaced with the Taqscreen MPXv2 test, which increased sensitivity from $22.8 \mathrm{IU} / \mathrm{ml}$ to $13.8 \mathrm{IU} / \mathrm{ml}$ for single donation screened in MP6. Since 2018, the Taqscreen MPX2 test was replaced by the cobas MPX test (sensitivity for single donation screened in MP6 increased from $13.8 \mathrm{IU} / \mathrm{ml}$ to $8.4 \mathrm{IU} / \mathrm{ml}$ ). Since 2014, the Ultrio Plus test was replaced with Ultrio Elite test (sensitivity $4.3 \mathrm{IU} / \mathrm{ml}$ ). Since 2017, some regional BTC used the Ultrio Elite test in 4 donation pools (sensitivity $17.2 \mathrm{IU} / \mathrm{ml}$ ). Table 1 and Figure 4 present changes in the sensitivity of HBV DNA detection in donor screening. Reactive NAT result for donations negative in HBsAg test obliges the BTC and the IHTM to launch procedures to confirm or exclude infection in the reactive sample. The procedures are described later on in the text.

\section{Procedures launched in BTC and in IHTM for reactive result of HBV DNA screening in HBsAg negative donations}

In the case of reactive NAT result in plasma pool or individual donation, appropriate confirmation algorithms were followed. Each NAT reactive result in individual donation at the BTC (confirmation stage I) had to be confirmed at the IHTM (confirmation stage II) on plasma sample forwarded by the BTC. Over the period under analysis the algorithm implemented at BTC had undergone changes and was closely related to the screening methods (Fig. 5 and 6, Table 1).

\section{Confirmation I stage in BTC}

In the case of a reactive result with Ampliscreen HBV test performed in MP24, it was necessary to test 6 donation subpools and then individual donations in order to identify the HBV infected donor/donation. Plasma from HBV DNA reactive donations was sent to IHTM (a/on Fig. 5).

When minipools of 6 donation (MP6) were found reactive with multiplex PCR-based tests it was necessary to identify the positive donation (s) (b/and b'/on Fig. 5) with Taqscreen MPXv1,
Taqscreen MPX2 and cobas MPX tests. All MPX tests were multiplex, but only the Taqscreen MPX2 and cobas MPX tests recognized the identified virus. Plasma from HBV DNA reactive donations was sent to IHTM (b/on Fig. 5). The Taqscreen MPXv1 test did not identify the detected virus and a differential test for multiplex reactive donation had to be performed at IHTM (b/in Fig. 5).

In the case of TMA based tests, when a multiplex reactive result was obtained:

- With the Ultrio HCV, HBV, HIV test in a single donation (IDT) in the years 2005-2007 it was necessary to perform DNA HBV, RNA HIV and RNA HCV differentiating tests against viruses detected in the Ultrio test to identify the detected virus. The dHBV differential assay was used to identify HBV. All Ultrio reactive plasma samples were sent to IHTM for HBV confirmatory stage II except those with RNA HCV and/ /or RNA HIV positive and DNA HBV negative in differentiating tests (a/Fig. 6). Such procedure was used because Ultrio test was more sensitive that $\mathrm{dHBV}$ test and $\mathrm{HBV}$ viremia can be very low, even below detection limit of dHBV test.

- In the years 2008-2011, for Ultrio HCV/HBV/ /HIV tests performed in individual donations (Ultrio Plus since 2011, Ultrio Elite since 2014), 5 tests had to be performed on the same sample: 2 replications of the multiplex test and 3 single differentiating test for each of the tested viruses $\mathrm{dHBV}, \mathrm{dHCV}$, dHIV. Plasma with min. 2 Ultrio reactive and/or min. 1 Ultrio and $\mathrm{dHBV}$ reactive results was sent to the IHTM (b/ Figure 6).

- In 2011-2020, for ULTRIO Plus/Elite HCV/ /HBV/HIV test performed in 8 or 4 donation pools, all donations in the reactive pool had to be tested individually with the Ultrio Plus/Elite $\mathrm{HCV} / \mathrm{HBV} / \mathrm{HIV}$ test, and then the reactive donation should be tested with a differential test. Plasma from donation $\mathrm{dHBV}$ reactive result was sent to IHTM (c/Fig. 6).

\section{Confirmation II stage in IHTM}

Verification (confirmation tests) at IHTM were performed on biological material from a previously unopened sample or from plasma bag (Tab. 1; Figs 5 and 6). The tests were performed on donations found reactive in BTC with:

a) IDT in tests

- Ultrio (a/ Figure 6) regardless of the differentiation test result;

- Ultrio Plus or Elite, but only for repeat reactive result in mutiplex (screening) test and/or the differentiating test (b/Fig. 6); 


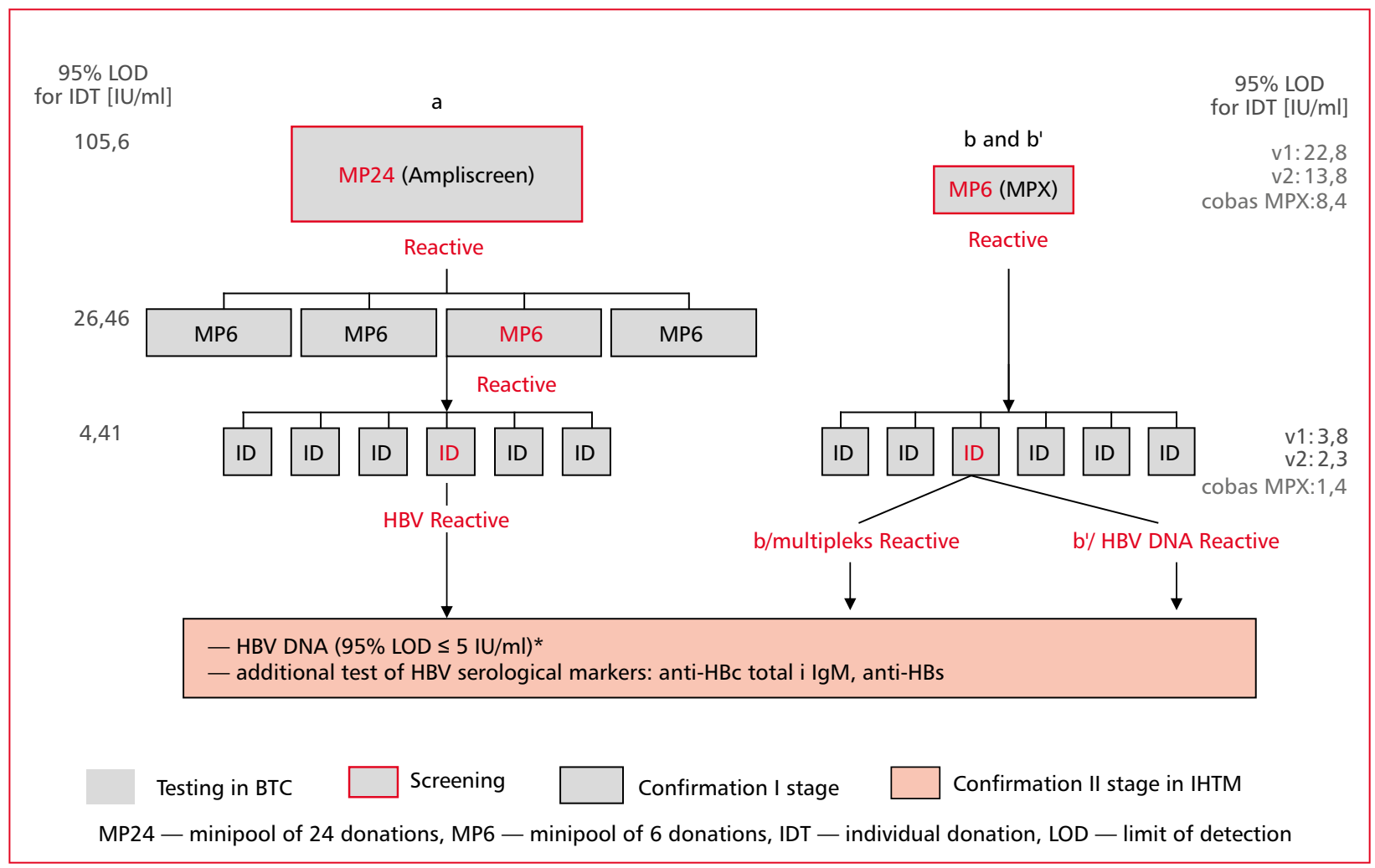

Figure 5. Procedure for reactive result in HBV DNA screening - PCR; *sensitivity according to instruction

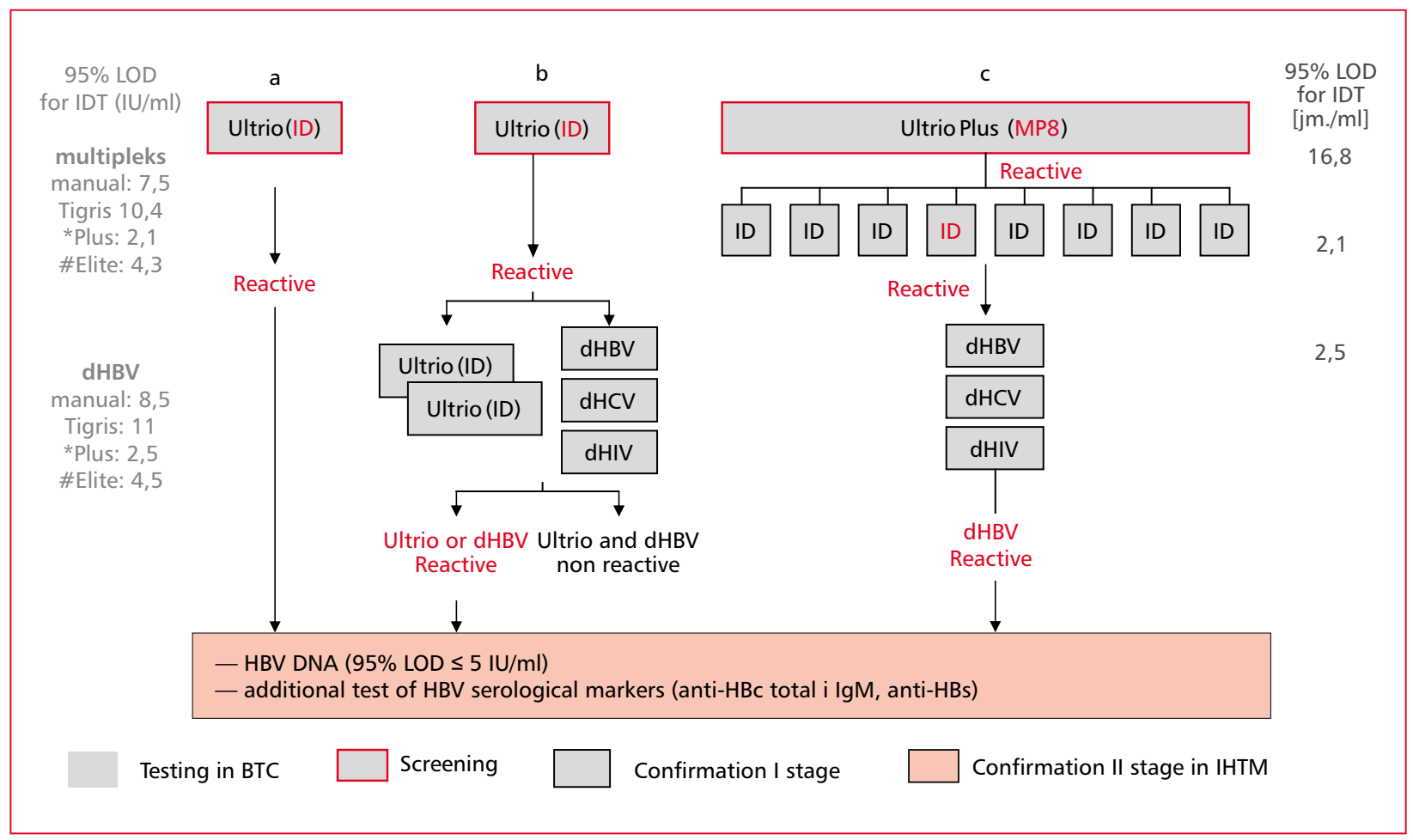

Figure 6. Procedure for reactive result in HBV DNA screening — TMA 
b) mini-pool tests with

- Ampliscreen MP24 (a/Fig. 5);

- Taqscreen MPXv1 (b/Fig. 5), Taqscreen MPXv2 and cobas MPX (b'/Fig. 5) MP6;

- Ultrio Plus MP8 (c/Fig. 6), Ultrio Elite MP4. Verification tests performed at IHTM to identify HBV infection included HBV DNA assays with sensitivity $<5 \mathrm{IU} / \mathrm{ml}$ (Ampliscreen HBV, Ultrio Plus, Ultrio Elite and GFE Blut, Germany) as well as anti-HBc total, anti-HBc IgM and anti-HBs serological markers (Architect, Abbott Diagnostics, Germany). The presence of individual markers in a donation found reactive in BTC allowed to determine the phase of donor infection (I, II WP or $\mathrm{OBI}$ ) and to forward the notification to the donor together with referral to primary care physician.

\section{Present and Future of HBV screening in blood donors}

Serologic HBsAg tests have been performed since the 1970s. In 2016, 44/46 European countries and $176 / 180$ countries worldwide reported $\mathrm{HBsAg}$ screening to WHO [1].

Since 1999, HBV nucleic acid testing (NAT) has gradually been added to the panel of tests in routine use [1, 49]. In 2016, HBV DNA testing was performed in the countries of: Europe ( $\mathrm{n}$ $=22)$, North and South America $(\mathrm{n}=4)$, Africa $(\mathrm{n}=2)$, the Middle East $(\mathrm{n}=5)$, the Western Pacific $(\mathrm{n}=7)$ and South-East Asia $(\mathrm{n}=2)$. In Poland as worldwide molecular screening tests are PCR and TMA-based and performed either in individual donations (IDT) or mini-pools (MP) [49]. Since 2017, the NAT screening tests recommended by the European Commission must be capable of detecting at least $100 \mathrm{IU}$ of HBV DNA/ml per donation regardless of the adopted strategy [7]. Each country selects its own testing approach/ /strategy (IDT or MP) as well as the mini-pool size (MP4-MP96); the choice depends upon epidemiological and economic analyses and the decisions are incorporated into national recommendations for the country's blood transfusion service [50, 51].

Countries with a history of HBV epidemics and obligatory neonatal hepatitis $B$ vaccination record a steady decline of $\mathrm{HBsAg}$-positive infection rate. No such reports are available for occult hepatitis B infections [52-55]. Outcome of HBV DNA screening demonstrates that higher sensitivity tests ensure more effective yield rate for OBI and WP infections [53, 56, 57]. On the other hand, anti-HBc tests are capable of detecting both $\mathrm{HBsAg}$-positive as well as occult anti-HBc-positive infections. Due to very low viral load and level-fluctuations OBI are more difficult to detect with HBV DNA tests $[9,58]$. In view of the above, there are ongoing disputes regarding the selection of an optimal screening panel for blood donors. In the USA, parallel testing of HBV DNA in MP-16 (sensitivity of $68.8 \mathrm{IU} / \mathrm{ml}$ ) and anti-HBc was found more effective than HBV DNA in MP-16 and HBsAg [9]. In the Republic of South Africa, the ID-NAT test alone was found more effective for reduction of the HBV transmission risk than MP (6-16) NAT in combination with $\mathrm{HBsAg}$ and anti-HBc tests in all donations, particularly with regard to regular donors. Similar yield was determined for first-time donors. The South African analyses presented at the 2019 Conference of International Plasma Fractionation Association (IPFA) demonstrate that the effectiveness of screening panels/strategies correlates mainly with test sensitivity while the impact of regional epidemics and incidence rate is merely marginal [Vermeulen M, IPFA, 2019]. The above suggests a variety of optimal testing strategies and no one, single universal approach. A separate strategy for Poland should therefore be developed.

In order to determine an optimal panel for HBV testing in Polish blood donors it is essential to perform analyses of the detection frequency for HBsAg and HBV DNA with the strategies used so far as well as risk calculation with each approach and test, including anti-HBc which has not as yet been used for donor screening. This is planned as the focal point of our next study.

\section{Acknowledgements}

The authors express their sincere gratitude to mgr Dorota Kubicka-Russel for her help in data processing.

\section{References}

1. Global Hepatitis Report 2017. Geneva: World Health Organization; 2017.

2. Kleinman SH, Lelie N, Busch MP. Infectivity of human immunodeficiency virus- 1 , hepatitis $\mathrm{C}$ virus, and hepatitis $\mathrm{B}$ virus and risk of transmission by transfusion. Transfusion. 2009; 49(11): 2454-2489, doi: 10.1111/j.1537-2995.2009.02322.x, indexed in Pubmed: 19682345.

3. Liang T. Hepatitis B: The virus and disease. Hepatology. 2009; 49(S5): S13-S21, doi: 10.1002/hep.22881, indexed in Pubmed: 19399811.

4. Liaw YF, Chu CM. Hepatitis B virus infection. The Lancet. 2009; 373(9663): 582-592, doi: 10.1016/s0140-6736(09)60207-5.

5. Allain J-P. Global epidemiology of occult HBV infection. Home. 2017; 2(5), doi: 10.21037/aob.2017.06.01.

6. DIRECTIVE 2002/98/EC OF THE EUROPEAN PARLIAMENT AND OF THE COUNCIL of 27 January 2003 setting standards 
of quality and safety for the collection, testing, processing, storage and distribution of human blood and blood components and amending Directive. 2001/83/EC.

7. Guide to the Preparation, Use and Quality Assurance of Blood Components, 19th Edition 2017. https://www.edqm.eu/en/blood-transfusion-guide.

8. Janssen M.P. The collection, testing and use of blood and blood components in Europe 2015 report. https://www.edqm.eu/en/ blood-transfusion-reports-70.html2015.

9. Dodd RY, Nguyen ML, Krysztof DE, et al. Blood donor testing for hepatitis B virus in the United States: is there a case for continuation of hepatitis B surface antigen detection? Transfusion. 2018; 58(9): 2166-2170, doi: 10.1111/trf.14784, indexed in Pubmed: 30144082.

10. Seed C, Allain J, Lozano M, et al. International Forum on Occult hepatitis B infection and transfusion safety. Vox Sanguinis. 2019; 114(4): e1-e35, doi: 10.1111/vox.12743.

11. Tsai KN, Kuo CF, Ou JHJ. Mechanisms of Hepatitis B Virus Persistence. Trends Microbiol. 2018; 26(1): 33-42, doi: 10.1016/j. tim.2017.07.006, indexed in Pubmed: 28823759.

12. Hong M, Bertoletti A. Tolerance and immunity to pathogens in early life: insights from HBV infection. Semin Immunopathol. 2017; 39(6): 643-652, doi: 10.1007/s00281-017-0641-1, indexed in Pubmed: 28685270.

13. Yoshikawa A, Gotanda Y, Itabashi M, et al. Japanese Red Cross NAT Screening Research Group. HBV NAT positive [corrected] blood donors in the early and late stages of HBV infection: analyses of the window period and kinetics of HBV DNA. Vox Sang. 2005; 88(2): 77-86, doi: 10.1111/j.1423-0410.2005.00602.x, indexed in Pubmed: 15720604.

14. Vermeulen M, Dickens C, Lelie N, et al. Hepatitis B virus transmission by blood transfusion during 4 years of individual-donation nucleic acid testing in South Africa: estimated and observed window period risk. Transfusion. 2012; 52(4): 880-892, doi: 10.1111/j.1537-2995.2011.03355.x, indexed in Pubmed: 21981386.

15. Trépo C, Chan H, Lok A. Hepatitis B virus infection. The Lancet. 2014; 384(9959): 2053-2063, doi: 10.1016/s0140-6736(14)602208.

16. Juszczyk J. Clinical course and consequences of hepatitis B infection. Vaccine. 2000; 18 Suppl 1: S23-S25, doi: 10.1016/s0264-410x(99)00457-0, indexed in Pubmed: 10683539.

17. Tu T, Budzinska MA, Shackel NA, et al. HBV DNA Integration: Molecular Mechanisms and Clinical Implications. Viruses. 2017; 9(4), doi: 10.3390/v9040075, indexed in Pubmed: 28394272.

18. Hu B, Wang R, Fu J, et al. Integration of hepatitis $B$ virus $\mathrm{S}$ gene impacts on hepatitis B surface antigen levels in patients with antiviral therapy. J Gastroenterol Hepatol. 2018; 33(7): 1389-1396, doi: 10.1111/jgh.14075, indexed in Pubmed: 29266382.

19. Raimondo G, Caccamo G, Filomia R, et al. Occult HBV infection. Semin Immunopathol. 2013; 35(1): 39-52, doi: 10.1007/s00281012-0327-7, indexed in Pubmed: 22829332.

20. Lampertico P, Agarwal K, Berg T, et al. EASL 2017 Clinical Practice Guidelines on the management of hepatitis B virus infection. J Hepatol. 2017; 67(2): 370-398, doi: 10.1016/j. jhep.2017.03.021.

21. Seto WK, Lo YR, Pawlotsky JM, et al. Chronic hepatitis B virus infection. The Lancet. 2018; 392(10161): 2313-2324, doi: 10.1016/s0140-6736(18)31865-8.

22. Korelitz JJ, Busch MP, Kleinman SH, et al. A method for estimating hepatitis $\mathrm{B}$ virus incidence rates in volunteer blood donors. National Heart, Lung, and Blood Institute Retrovirus Epide- miology Donor Study. Transfusion. 1997; 37(6): 634-640, doi: 10.1046/j.1537-2995.1997.37697335159.x, indexed in Pubmed: 9191825.

23. Scheiblauer H, El-Nageh M, Diaz S, et al. Performance evaluation of 70 hepatitis B virus (HBV) surface antigen (HBsAg) assays from around the world by a geographically diverse panel with an array of HBV genotypes and HBsAg subtypes. Vox Sang. 2010; 98(3 Pt 2): 403-414, doi: 10.1111/j.1423-0410.2009.01272.x, indexed in Pubmed: 20412171.

24. Shinkai N, Kusumoto S, Murakami S, et al. Novel monitoring of hepatitis B reactivation based on ultra-high sensitive hepatitis B surface antigen assay. Liver Int. 2017; 37(8): 1138-1147, doi: 10.1111/liv.13349, indexed in Pubmed: 27992664.

25. Deguchi M, Kagita M, Yoshioka N, et al. Evaluation of the highly sensitive chemiluminescent enzyme immunoassay „Lumipulse HBsAg-HQ" for hepatitis B virus screening. J Clin Lab Anal. 2018; 32(4): e22334, doi: 10.1002/jcla.22334, indexed in Pubmed: 28984383.

26. Pondé RAA. Atypical serological profiles in hepatitis B virus infection. Eur J Clin Microbiol Infect Dis. 2013; 32(4): 461-476, doi: 10.1007/s10096-012-1781-9, indexed in Pubmed: 23192489.

27. Hsu HY, Chang MH, Ni YH, et al. Chronologic changes in serum hepatitis B virus DNA, genotypes, surface antigen mutants and reverse transcriptase mutants during 25-year nationwide immunization in Taiwan. J Viral Hepat. 2017; 24(8): 645-653, doi: 10.1111/jvh.12687, indexed in Pubmed: 28182307.

28. Candotti D, Laperche S. Hepatitis B Virus Blood Screening: Need for Reappraisal of Blood Safety Measures? Front Med (Lausanne). 2018; 5: 29, doi: 10.3389/fmed.2018.00029, indexed in Pubmed: 29515997.

29. Vermeulen M, van Drimmelen H, Coleman C, et al. A mathematical approach to estimate the efficacy of individual-donation and minipool nucleic acid amplification test options in preventing transmission risk by window period and occult hepatitis B virus infections. Transfusion. 2014; 54(10): 2496-2504, doi: 10.1111/ trf.12657, indexed in Pubmed: 24749834.

30. Zhang $\mathrm{ZH}, \mathrm{Wu} \mathrm{CC}$, Chen XW, et al. Genetic variation of hepatitis $\mathrm{B}$ virus and its significance for pathogenesis. World J Gastroenterol. 2016; 22(1): 126-144, doi: 10.3748/wjg.v22.i1.126, indexed in Pubmed: 26755865.

31. Brojer E, Grabarczyk P, Liszewski G, et al. Polish Blood Transfusion Service Viral Study Group. Characterization of HBV DNA+/ HBsAg- blood donors in Poland identified by triplex NAT. Hepatology. 2006; 44(6): 1666-1674, doi: 10.1002/hep.21413, indexed in Pubmed: 17133474.

32. Candotti D, Grabarczyk P, Ghiazza P, et al. Characterization of occult hepatitis B virus from blood donors carrying genotype A2 or genotype D strains. J Hepatol. 2008; 49(4): 537-547, doi: 10.1016/j.jhep.2008.04.017, indexed in Pubmed: 18602718.

33. Grabarczyk P, Garmiri P, Liszewski G, et al. Polish Blood Transfusion Centres Viral Study Group. Molecular and serological characterization of hepatitis B virus genotype A and D infected blood donors in Poland. J Viral Hepat. 2010; 17(6): 444-452, doi: 10.1111/j.1365-2893.2009.01192.x, indexed in Pubmed: 19780948.

34. Lelie N, Bruhn R, Busch M, et al. International NAT Study Group. Detection of different categories of hepatitis B virus (HBV) infection in a multi-regional study comparing the clinical sensitivity of hepatitis B surface antigen and HBV-DNA testing. Transfusion. 2017; 57(1): 24-35, doi: 10.1111/trf.13819, indexed in Pubmed: 27673757. 
35. Gerlich WH. Prophylactic vaccination against hepatitis B: achievements, challenges and perspectives. Med Microbiol Immunol. 2015; 204(1): 39-55, doi: 10.1007/s00430-014-0373-y, indexed in Pubmed: 25523195.

36. Kleinman SH, Busch MP. Assessing the impact of HBV NAT on window period reduction and residual risk. J Clin Virol. 2006; 36 Suppl 1: S23-S29, doi: 10.1016/s1386-6532(06)80005-3, indexed in Pubmed: 16831689.

37. Weusten J, Vermeulen M, van Drimmelen H, et al. Refinement of a viral transmission risk model for blood donations in seroconversion window phase screened by nucleic acid testing in different pool sizes and repeat test algorithms. Transfusion. 2011; 51(1): 203-215, doi: 10.1111/j.1537-2995.2010.02804.x, indexed in Pubmed: 20707858.

38. Coppola N, Sagnelli C, Pisaturo M, et al. Clinical and virological characteristics associated with severe acute hepatitis B. Clin Microbiol Infect. 2014; 20(12): O991-O997, doi: 10.1111/14690691.12720, indexed in Pubmed: 24930916.

39. Ciupe SM. Modeling the dynamics of hepatitis B infection, immunity, and drug therapy. Immunol Rev. 2018; 285(1): 38-54, doi: 10.1111/imr.12686, indexed in Pubmed: 30129194.

40. Raimondo G, Allain JP, Brunetto MR, et al. Statements from the Taormina expert meeting on occult hepatitis B virus infection. J Hepatol. 2008; 49(4): 652-657, doi: 10.1016/j.jhep.2008.07.014, indexed in Pubmed: 18715666.

41. Raimondo G, Locarnini S, Pollicino T, et al. Update of the statements on biology and clinical impact of occult hepatitis $\mathrm{B}$ virus infection. J Hepatol. 2019; 71(2): 397-408, doi: 10.1016/j. jhep.2019.03.034.

42. Levicnik-Stezinar S, Rahne-Potokar U, Candotti D, et al. Anti-HBs positive occult hepatitis B virus carrier blood infectious in two transfusion recipients. J Hepatol. 2008; 48(6): 1022 -1025, doi: 10.1016/j.jhep.2008.02.016, indexed in Pubmed: 18436328.

43. Zheng X, Ye X, Zhang L, et al. Characterization of occult hepatitis $\mathrm{B}$ virus infection from blood donors in China. J Clin Microbiol. 2011; 49(5): 1730-1737, doi: 10.1128/JCM.00145-11, indexed in Pubmed: 21411575.

44. Guo Z, Fu P, Yin Y, et al. The characteristics of hepatitis B surface antigen (HBsAg)-negative hepatitis B virus (HBV) infection in Chinese blood donors: a follow-up study of donors tested negative for HBsAg and reactive for simultaneous nucleic acid testing of $\mathrm{HBV}$, hepatitis $\mathrm{C}$ virus, and human immunodeficiency virus. Transfusion. 2017; 57(3pt2): 832-840, doi: 10.1111/trf.14014, indexed in Pubmed: 28164313.

45. Obwieszczenie MinistraZdrowia $\mathrm{z}$ dnia 9 czerwca 2017 r. w sprawie wymagań dobrej praktyki pobierania krwi i jej składników, badania, preparatyki, przechowywania, wydawania i transportu dla jednostek organizacyjnych publicznej służby krwi. Ustawa $z$ dnia 22sierpnia 1997 r. o publicznej służbie krwi (Dz. U. Nr 106, poz. 681 z późn. zmian).
46. Łętowska M. (red.). Medyczne zasady pobierania krwi, oddzielania jej składników i wydawania, obowiązujące w jednostkach organizacyjnych publicznej służby krwi. Instytut Hematologii i Transfuzjologii; Warszawa 2006 (wersja 4; 2010).

47. Łętowska M. (red.). Medyczne zasady pobierania krwi, oddzielania jej składników i wydawania, obowiązujące w jednostkach organizacyjnych publicznej służby krwi. Instytut Hematologii i Transfuzjologii; wydanie II; 2011.

48. Łętowska M. (red.). Medyczne zasady pobierania krwi, oddzielania jej składników i wydawania, obowiązujące w jednostkach organizacyjnych publicznej służby krwi. Instytut Hematologii i Transfuzjologii; wydanie III, 2014.

49. Roth WKea. International survey on NAT testing of blood donations: exanding imlementation and yield from 1999 to 2009. Vox Sanguinis; 2012; 82-90.

50. Stramer SL, Notari EP, Krysztof DE, et al. Hepatitis B virus testing by minipool nucleic acid testing: does it improve blood safety? Transfusion. 2013; 53(10 Pt 2): 2449-2458, doi: 10.1111/ trf.12213, indexed in Pubmed: 23607261.

51. Stolz M, Tinguely C, Fontana S, et al. Hepatitis B virus DNA viral load determination in hepatitis B surface antigen-negative Swiss blood donors. Transfusion. 2014; 54(11): 2961-2967, doi: 10.1111/trf.12694, indexed in Pubmed: 24805974.

52. Kopacz A, Gdowska J, Gorska J, et al. Sensitivity of the Ultrio and Ultrio Plus Assay versions in detecting window period and occult hepatitis B infection in Polish blood donors. Vox Sanguinis. 2013; 105: 178-178.

53. Tsoi WC, Lelie N, Lin CK. Enhanced detection of hepatitis B virus in Hong Kong blood donors after introduction of a more sensitive transcription-mediated amplification assay. Transfusion. 2013; 53(10 Pt 2): 2477-2488, doi: 10.1111/trf.12165, indexed in Pubmed: 23521050.

54. Grabarczyk P, Kopacz A, Sulkowska E, et al. Blood donors screening for blood born viruses in Poland. Przegl. Epidemiol. 2015; 69(3): 473-7, 591, indexed in Pubmed: 26519842.

55. Ramachandran S, Groves J, Xia G, et al. Recent and occult hepatitis B virus infections among blood donors in the United States. Transfusion. 2018; 59(2): 601-611, doi: 10.1111/trf.15057.

56. Vermeulen M, Coleman C, Lelie N, et al. Enhancement of HBV NAT yield rate after introduction of the Ultrio Plus Assay. Vox Sanguinis. 2012; 103: 161-161.

57. Grabarczyk P, van Drimmelen H, Kopacz A, et al. Head-to-head comparison of two transcription-mediated amplification assay versions for detection of hepatitis $B$ virus, hepatitis $C$ virus, and human immunodeficiency virus Type 1 in blood donors. Transfusion. 2013; 53(10 Pt 2): 2512-2524, doi: 10.1111/trf.12190, indexed in Pubmed: 23590145.

58. Stramer SL, Zou S, Notari EP, et al. Blood donation screening for hepatitis B virus markers in the era of nucleic acid testing: are all tests of value? Transfusion. 2012; 52(2): 440-446, doi: 10.1111/j.1537-2995.2011.03283.x, indexed in Pubmed: 21810101. 